\title{
CONTRIBUTIONS TO THE TAXONOMY AND BIOGEOGRAPHY OF THE GENUS DICHAGYRIS (SUBG. DICHAGYRIS) LEDERER, 1867 (LEPIDOPTERA, NOCTUIDAE, NOCTUINAE)
}

\author{
Zoltán VARGA ${ }^{1}$, GÁbor RonkAY² and LÁsZló RonKAY ${ }^{2,3}$ \\ ${ }^{1}$ Department of Evolutionary Zoology and Human Biology, University of Debrecen \\ H-4032 Debrecen, Egyetem tér 1, Hungary \\ E-mail: varga.zoltan@science.unideb.hu; https://orcid.org/0000-0001-2324-6931 \\ ${ }^{2}$ Heterocera Ltd; H-1137 Budapest, Szent István krt 4, Hungary \\ E-mail: gaborronkay@gmail.com, https://orcid.org/0000-0001-8571-6312 \\ ${ }^{3}$ Hungarian Natural History Museum, H-1088 Budapest, Baross utca 13, Hungary \\ E-mail: laszlo.ronkay2@gmail.com; https://orcid.org/0000-0001-9153-4902
}

The taxonomically important characters and subgeneric subdivision of Dichagyris are presented with several historical and nomenclatural considerations. Subdivision of D. vallesiaca is revised based on the type material of the known subspecies. The D. psammochroa group is revised, with description of a new species, D. kurbatskyi from Kazakhstan, and one new subspecies, D. psammochroa kopetdaghimena from the Kopet-Dagh massif. The D. taftana group is revised, with the description of a new species (D. guentereberti from Afghanistan) and two new subspecies (D. taftana elborsasta and D. taftana safavida, from different areas of Iran). The eastern sister species of D. humilis, D. hypotacta from Afghanistan and Pakistan, is described. Major phylogenetic clades of Dichagyris s. str. are associated to western Palaearctic and/or Central Asiatic mountainous regions. Core areas of allopatric speciation of Dichagyris s. str. are discussed with taxonomic considerations and outlook on the subgenera Yigoga and Albocosta, as well.

Key words: species groups, lectotype designations, new species, new subspecies, vicariance, allopatric speciation, Holarctic, Sino-Himalayan, xeromontane.

\section{INTRODUCTION}

Species groups of the subgenus Dichagyris Lederer, 1867

The recent interpretation of the genus Dichagyris Lederer, 1867 can be attributed to KozHantshikov (1930). In his seminal, but mostly neglected, review paper a set of species were merged into this genus, which have been earlier considered as Agrotis Ochsenheimer, 1816 or Euxoa Hübner, 1821 (Staudinger \& Wocke 1871, Hampson 1898), or Rhyacia Hübner, 1821 (WarREN 1913), based on the very homogeneous general appearance, colouration and pattern, and also on the rather uniform genitalia of both sexes. Later, this genus was placed to the tribe Agrotini of the subfamily Noctuinae (FIbIger 1990, 1997, Fibiger \& Lafontaine 2005, Lafontaine \& Fibiger 2006) which was more recently downgraded as subtribe Agrotina of Noctuini (LAFONTAINE 
\& SснміDт 2010) based primarily on the results of molecular phylogenetic surveys on Noctuoidea, and Noctuidae, respectively (Mitchell et al. 2006, ZAHIRI et al. 2013, Regier et al. 2017; see: "core Noctuinae").

The highly diverse and species-rich genus Dichagyris can be characterised by a number of genitalia features. In the male genitalia, the genital capsule is fairly uniform and simple displaying the following characters; uncus falcate, acute apically, and not spatulate (as in most Actebia s.l. Stephens, 1829), free arm of harpe (clasper) well developed; ampulla weakly or moderately sclerotised; saccular processes absent (in contrast to some subgenera of Actebia), cucullus and corona most often well developed (reduced only in a few species groups); clavus generally short, finger-shaped, neither fused with juxta nor basal part of sacculus; ventral carinal plate forms a sclerotised bar, rarely dentate or armed by small, acute spines; vesica elongate-tubular, often retroflexed or helicoidal, without fasciculate cornuti; subbasal diverticulum present, armed with tiny subbasal cornutus. The female genitalia are characterised by the weakly or moderately sclerotised papillae anales; the weakly sclerotised, mostly membranous antrum and ductus bursae; the bilobate bursa copulatrix with usually elongate-tubular, often slightly saccate corpus bursae, lacking signa and either long, tubular, or shorter, more or less elongate-globular appendix bursae.

Most Palaearctic Dichagyris species belong to five subgenera: Dichagyris s. str. with numerous species groups (including the three species groups of Yigoga Nye, 1975, considered also as an own subgenus, see Fibiger 1990, 1997, Fibiger \& Lafontaine 2005), the monotypical Phleboeis Christoph, 1887, the oligotypical Stenosomides Strand, 1942 and Basistriga Fibiger et Lafontaine, 1997, and the species-rich Albocosta Fibiger et Lafontaine, 1997, the latter is subdivided into at least two species groups. Additionally, there are several fairly isolated species and species groups, mostly in the Sino-Himalayan area. They have been earlier attributed either to Yigoga or to Albocosta; their proper taxonomic affiliation should be considered later. According to LafontaIne (2004) four further North American subgenera (Loxagrotis McDunnough, 1929, Pseudorichia Lafontaine, 2004, Pseudorthosia Grote, 1874 and Mesembragrotis Barnes et Benjamin, 1927) have been also allied to Dichagyris s.l.

The first attempt to outline the species groups within Dichagyris was performed by Kоzналтsнiкоv (1930). He excluded some species groups from Dichagyris as "Ochropleura" based on external similarity, e.g. the species with light costal stripe, considered recently as Albocosta, also the renigera-forficula group, and the species groups later considered as subg. Yigoga, etc. The rest of species was subdivided into two main groups. The larger group includes the type species D. melanura* and further 15 species, as opposed to the other

* The complete names of species, author(s) and years of description are given in Appendix 
group, consisting only of D. umbrifera and D. jacobsoni. Within the larger, more diverse group he separated $D$. vallesiaca and its closest relatives (D. squalorum, D. crymaea, D. inexpectata, D. subsqualorum and D. venosa), on one hand, and the more isolated D. tyrannus, D. striata, D. nigrolineata, D. squalidior and D. kirghisa on the other hand. The subdivision of the first, the "vallesiaca" group was based on his own species descriptions, and on the survey of the Eversmann's type of $D$. squalorum. It was shown by the published figures that this species is extremely close to $D$. vallesiaca, and clearly differs from the often co-occurring D. squalorum (sensu Boursin and auctorum), which was compared with D. squalidior and correctly described as D. nigrolineata Kozhantshikov, 1930.

The taxonomic consequences of these actions can be summarised as follows:

- Dichagyris nigrolineata Kozhantshikov, Russkoye Entomologicheskoye Obozrenie 24: 11, ff. 16, 40; Corti \& Draudt 1933: 57, T7d = D. squalorum auctorum nec Eversmann, 1856.

- $\quad$ Agrotis squalorum Eversmann, 1856, Bulletin de la Société Impériale des Naturalistes de Moscou 2: 221; Corti \& Draudt 1933: 57, T7e. = Agrotis vallesiaca Boisduval, [1837]; Icones Historiques des Lépidoptères d'Europe, nouveaux ou peu connus. Collection, avec Figures coloriées, des Papillons d'Europe 2: pl. 78, f. (junior synonym at species level).

\section{MATERIAL AND METHODS}

The method of surveys was traditional taxonomic, based on materials of state museums and private collections, electronic databases and large set of digitalised microscopic slides. We revised the comprehensive type material and other important voucher specimens from several internationally important European collections (see: Abbreviations).

The genital dissections were made by the technique published by Robinson (1976), with certain modifications (FIBIGER 1997). Potassium hydroxide (15\% solution $\mathrm{KOH})$ was used to macerate the full abdomen. The cleaned genital capsule, everted vesica and female copulatory organ were dehydrated in $96 \%$ ethanol; the weakly sclerotized structures were stained with chlorazol black then mounted to Euparal.

The mounted slides were digitalised with microscopic slide scanner type GT Vision PrimeScan Microscope Slide Scanner. Terminology of genitalia follows the publications of Lafontaine $(1987,1998)$.

Abbreviations: BMNH - Natural History Museum, London (formerly British Museum, Natural History); HNHM - Hungarian Natural History Museum, Budapest; GYP slide of Péter Gyulai; MHNG - Museum d'Histoire Naturelle, Genève; NHMW - Naturhistorisches Museum, Wien; NRS - Naturhistoriska Riksmuseet, Stockholm; RL - slide of László Ronkay; SMNK - Staatliches Museum für Naturkunde, Karlsruhe; VZ - slide of Zoltán Varga; ZFMK - Zoologisches Forschungsmuseum Alexander Koenig, Bonn; ZSM Zoologische Staatssammlung, München. 


\section{RESULTS}

Taxonomy of the Dichagyris vallesiaca group

Subspecies of $D$. vallesiaca, based on revision of the type specimens. This species is subdivided to four widely distributed, and two fairly isolated subspecies. The two western subspecies, the nominotypical $D$. vallesiaca vallesiaca (Boisduval, [1837]) and D. vallesiaca crymaea Kozhantshikov, 1930, have the most restricted ranges. The widely distributed taxa are distributed from the steppes of southern Russia (D. vallesiaca squalorum (Eversmann, 1856); stat. revid., type locality: Guberli in southern Urals) to southern Siberia and western Mongolia (D. vallesiaca inexpectata Kozhantshikov, 1925, type locality Minussinsk), and from Asia Minor, Caucasus region, Iran and Turkmenistan (D. vallesiaca subsqualorum Kozhantshikov, 1930; type locality: Georgia; Fig. 33) to the high mountains of Central Asia (Tien Shan, Hindukush, Pamirs: D. vallesiaca venosa Kozhantshikov, 1930; type locality: Pamirs, Khorog, Fig. 34). The latter seems to be parapatric with the sister species occurring in the Karakoram and Himalaya Mts (D. fuscashmiriana Ronkay, Ronkay et Varga, 2020; type locality: Pakistan, Kashmir, Deosai Mts, Fig. 35).

Dichagyris griseotincta (Agrotis (Dichagyris) griseotincta Wagner, 1931; 476; Type locality: Turkey, prov. Kayseri, near Sultan Dagh, Fig. 36) is a species occurring sympatrically with $D$. vallesiaca subsqualorum in Central Anatolia, mostly in provinces Konya, Kayseri and Sivas, in low or medium altitudes, often with halophytic vegetation (e.g. at Tuz Gölü). The completely retroflexed vesica with nearly $360^{\circ}$ coiling is synapomorphic with that of $D$. vallesiaca, the genital capsule is, however, strongly differentiated, having more elongate valvae; shorter, slenderer and pointed harpe, and conical, strong sclerotisation fused to the dorsal margin of the juxta.

\section{Taxonomy of the D. psammochroa group}

with the description of a new species and a new subspecies

The psammochroa species group consists of smaller to medium-sized moths with relatively slender body, narrow forewings with light brown to ochreous-brown ground colour, usually with dimorphic noctuid pattern (either with well-defined maculation or with blurred markings and contrasting dark brownish marginal field; see: D. psammochroa and ssp. dichroa, typical for the populations of the Fars province). Male genitalia are characterised by the distally tapering valvae with well-developed corona; the strong and long harpe, surpassing dorsal margin of valva, and by the relatively short, semihelicoidal vesica with subbasal diverticulum bearing a needle-shaped cornutus. In female genitalia, the ovipositor is weakly sclerotised, with relatively 
short apophyses, and the appendix bursae is short, globular. The male genital characters are figured by VARGA (1993).

The group consists of six species, five of them are strictly localised, and only D. psammochroa is more widely distributed. General distribution: (i) $D i$ chagyris cataleipa - isolated species in Eastern Asia Minor; (ii) Dichagyris psammochroa - three subspecies: D. p. psammochroa - Elburs Mts (Fig. 37), D. psammochroa dichroa - Zagros Mts (Iran, Fars); D. psammochroa kopetdaghimena ssp. n. (Fig. 43) - Kopet-Dagh Mts in Turkmenistan and Iran, described below; (iii) Dichagyris afghana (Fig. 38) - Central part of Hindukush, from Koh-i-Baba Mts to Panjshir valley and Badakhshan; (iv) D. apochora - western Pamirs; (v) D. kurbatskyi sp. n. - Kazakhstan, Prov. Almaty, described below.

\section{Dichagyris kurbatskyi sp. n.}

(Figs 1-4, 39-42)

Holotype. Male, Kazakhstan, Prov. Almaty, Mt. Toraygir, Pass Alasay, 1600 m, 7857’ E, 43¹7’N, 1.VIII.1995, leg. Fábián \& Varga, slide No. VZ10087m (coll. Varga, SMNK) (Fig. 39).

Paratypes. Kazakhstan, Prov. Almaty. 7 males, 2 females, with same data as holotype (colls Gy. Fábián, P. Gyulai, G. Ronkay and Z. Varga).

Slide Nos: VZ10094m (Fig. 40), VZ10095m (Fig. 41), VZ10256f (Fig. 42).

Diagnosis. This species is on average somewhat larger with its wingspan $35-38 \mathrm{~mm}$ than all but one species of this group, only D. apochora is similar in size to D. kurbatskyi. The forewing ground colour is light brownish-ochreous grey, not sandy ochreous as in its relatives, and the forewing markings, especially the crenulate postmedian line, are more distinctly marked than in the closely related D. psammochroa (Figs 9-10) and D. afghana (Figs 7-8). The species is somewhat similar also to the co-occurring D. clara (Figs 5-6), but the forewings of $D$. clara are more concolorous ochreous-grey, the crosslines are finer and sharper defined, and the hindwing is also darker, light fuscous grey. The females of D. clara can be easily distinguished from D. kurbatskyi also by the much stronger sclerotised ovipositor.

Description. Ground colour of head, thorax and forewings very light brownish ochreous-grey, interspersed with darker brown hairs and scales. Forewing noctuid maculation faint, defined with a few darker grey scales only; crosslines simple, blackish-brown, with blackish-brown spots on costa; antemedial line and median shadow zigzagged; postmedian line crenulate; submarginal field brownish-ochreous; subterminal line represented by zigzagged, diffuse blackish-brown shadow; inner part of the cilia darker brown chequered. Hindwings shining whitish with diffuse light brownish-grey marginal area and white cilia. Sexes similar, the hindwings of the females slightly darker.

Male genitalia (Figs 39-41): Very similar to those of the other species of the species group. Valvae somewhat broader with stronger, less falcate harpe; the helicoidal vesica is also generally similar to that of the other species of the group but the subbasal diverticu- 
lum is bubble-shaped with somewhat smaller needle-like cornutus, and its medial part has a small pocket-shaped diverticulum which cannot be observed in any related species.

Female genitalia (Fig. 42): papillae anales weakly sclerotised, quadratic, finely ciliate (more sclerotised and acutely pointed in D. clara, with strong setae); antrum with U-shaped bilateral sclerotisation; ductus bursae very short, shorter than in the related species; appendix bursae subglobular, remarkably shorter than corpus bursae.

Bionomics and distribution. The new species is known from the type locality only. Its habitat is a moderately grazed plateau at medium altitudes of the Toraygir Mts in southern Kazakhstan, Almaty province.

Etymology. The new species is gratefully dedicated to Mr. Vladimir Kurbatsky for his friendly helpfulness during the expeditions of G. Fábián, A. Orosz, and Z. Varga in Kazakhstan.

\section{Dichagyris psammochroa kopetdaghimena ssp. n.}

$$
\text { (Figs 11-14, 43) }
$$

Holotype. Male, Iran, Prov. Khorasan, Kopet-Dagh Mts, $10 \mathrm{~km} \mathrm{~N}$ of Jevenly, Tandure NP, 2300 m, 9-10.VII.2010, leg. P. Gyulai \& A. Garai (coll. P. Gyulai, later to be deposited in the HNHM).

Paratypes. Iran, Prov. Khorasan. 1 male, 2 females, with same data as holotype (coll. P. Gyulai); 1 male, 1 female, Kopet-Dagh Mts, Qucan, 2000 m, 10.VII.2005, leg. T. Hácz, G. Petrányi \& I. Juhász (coll. P. Gyulai); 4 males, Kopet-Dagh Mts, 50 km NE of Qucan, 2000 m, 13.VII.2005, leg. B. Benedek (colls P. Gyulai, G. Ronkay); 5 males, Kopet-Dagh, 80 km NE of Qucan, 2000 m, 14-15.VII.2005, leg. B. Benedek (colls P. Gyulai, G. Ronkay, Z. Varga); 1 male, Kuh-e-Binaloud, 1770 m, NE of Neyshapur, 7-8.VII.2010, leg. P. Gyulai \& A. Garai (coll. P. Gyulai); 1 male, Binaloud, 2507 m, N36²8,56', E59 ${ }^{\circ} 46,17^{\prime}$, 10.IX.2012, leg. M. M. Rabieh (coll. P. Gyulai). Slide No VZ9321m. Turkmenistan. 10 males, 2 females, Kopet-Dagh Mts, Dushak Mt., 5754'E, 3757’ N, 2300-2400 m, 9-12.VIII.1992, Nos L70 and L71, leg. M. Hreblay, Gy. László, G. Ronkay (colls G. Ronkay and Varga); 2 males, with same data, MHNG ENTO 20676 and 20677 (coll. J. Plante, MHNG); 1 male, Kopet-Dagh Mts, 15 km W of Firyuza, Dushak Mt., 2100-2200 m, 3-13.VII.1990, leg. V. V. Dubatolov \& T.D. Dubatolova (coll. G. Ronkay); 1 male, with same data, MHNG ENTO 20678 (coll. J. Plante, MHNG). Slide Nos VZ6778m, VZ9322m (Fig. 43).

Diagnosis. This subspecies is on average slightly smaller than the typical subspecies and D. psammochroa dichroa with its wingspan 31-34 mm (most frequently $32 \mathrm{~mm}$ ). Head, thorax and forewings light ochreous-brown, collar and tegulae with some reddish tint. Forewing light ground colour more or less suppressed by dark brown irroration, being essentially stronger than in the subspecies psammochroa (Figs 9-10) and dichroa (the "dichroa" form rarely occurs as individual form also within the typical subspecies). Crosslines, medial shadow and submarginal field dark brown, antemedial line interrupted, postmedian line crenulate; noctuid maculation defined by dark brown scales and dark brown intermaculation. Cilia medially subdivided, inner part ochreous brown, outer part white. Hindwing shining white with diffuse ochreousgrey margin and white cilia. 
The male genitalia (Fig. 43) are generally similar to those of the nominotypical subspecies (Fig. 37), having shorter clavus and somewhat shorter and distally more tapering valvae. The female genitalia of the ssp. kopetdaghimena
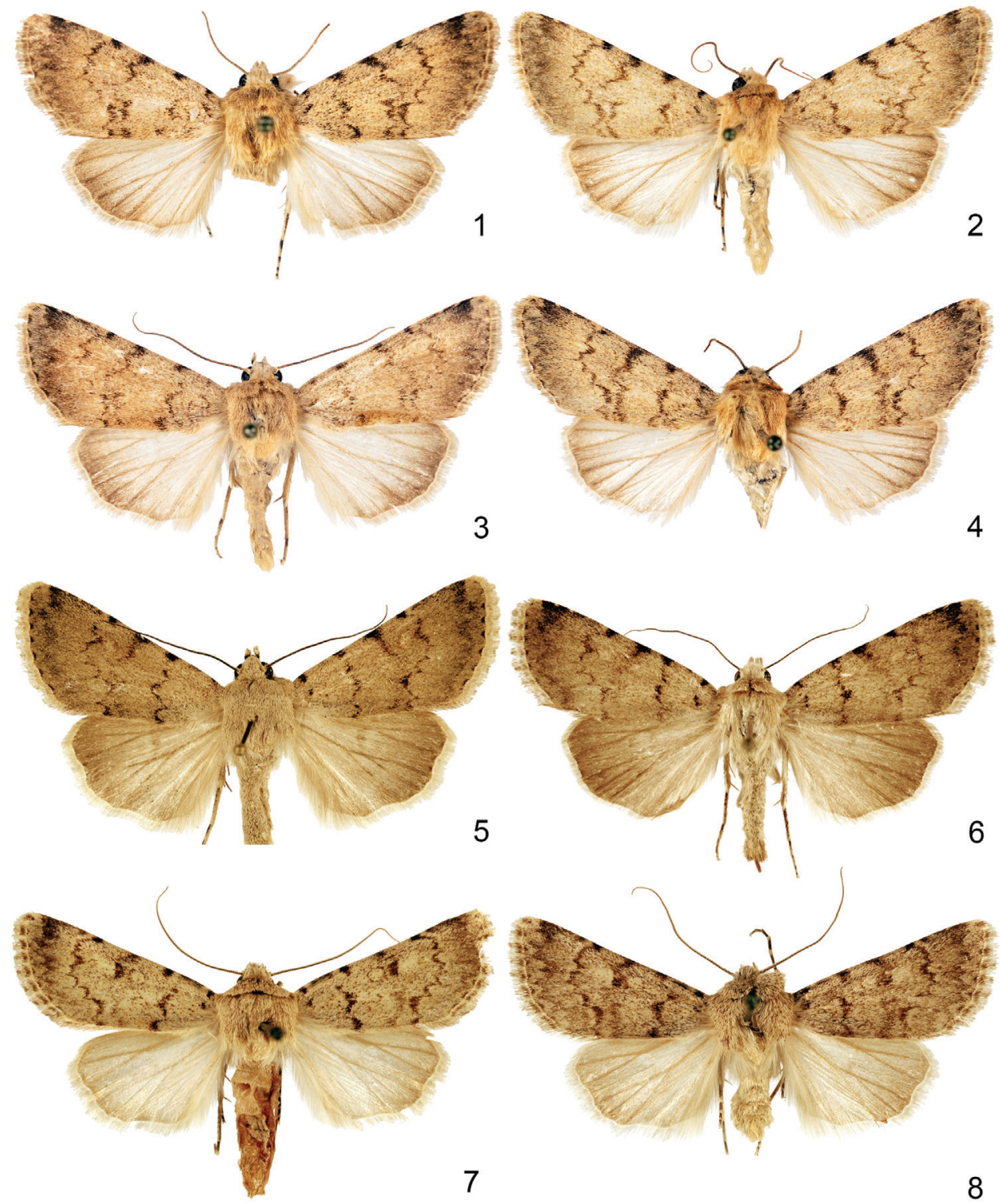

Figs 1-8. Dichagyris spp.: 1-4 = Dichagyris kurbatskyi sp. n. 1 = holotype, male, Kazakhstan, Toraygir Mts; $2-4=$ paratypes males, Kazakhstan, Toraygir Mts; 5-6 = D. clara (Staudinger, 1888); 5 = male, 6 = female, Kazakhstan, Toraygir Mts; 7-8 = D. afghana Boursin, 1963: $7=$ holotype, male, Afghanistan, Paghman Mts; 8 = paratype, male, Afghanistan, Paghman Mts 
are also similar to those of the other subspecies, only the appendix bursae is proportionally somewhat shorter.

Bionomics and distribution. The ssp. kopetdaghimena occurs in the Binaloud and Kopet-Dagh mountains in Khorasan province of Iran and in Turk-
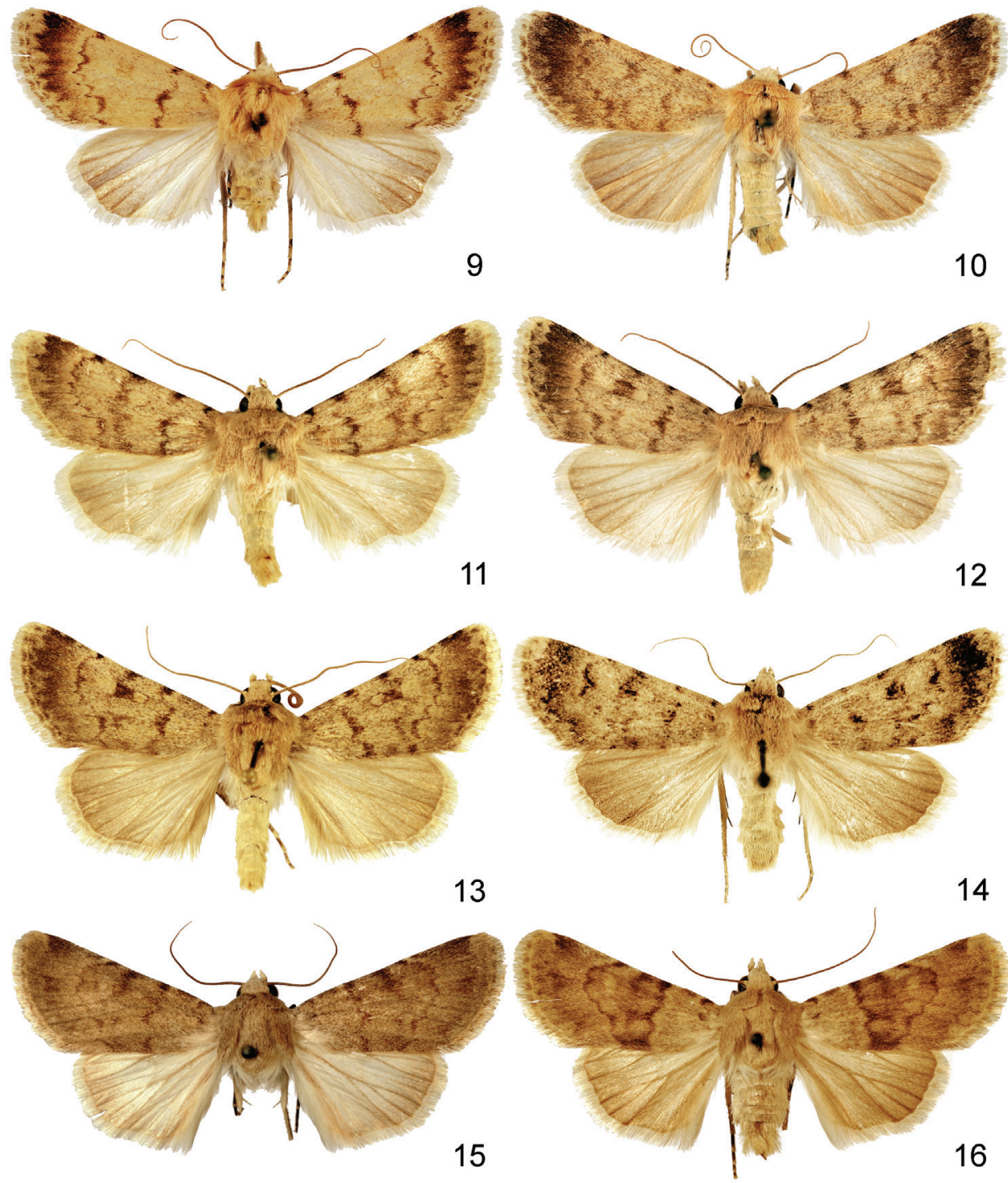

Figs 9-16. Dichagyris spp.: 9-10 = D. psammochroa psammochroa (Boursin, 1940), 9 = male, 10 = female, Iran, Elburz Mts; 11-14 = D. psammochroa kopetdaghimena ssp. n.: 11-12 = paratype males, Iran, Khorassan, Kopet-Dagh, 13 = paratype, male, Turkmenistan, Kopet-Dagh, 14 = paratype, female, Turkmenistan, Kopet-Dagh; $15-16=$ D. taftana taftana Brandt, 1941 :

15 = holotype, male, Iran, Baluchestan, Kuh-i-Taftan, 16 = paratype, same data as 15 
menistan. Its habitats are rupicolous mountain steppes in medium-high and high altitudes.

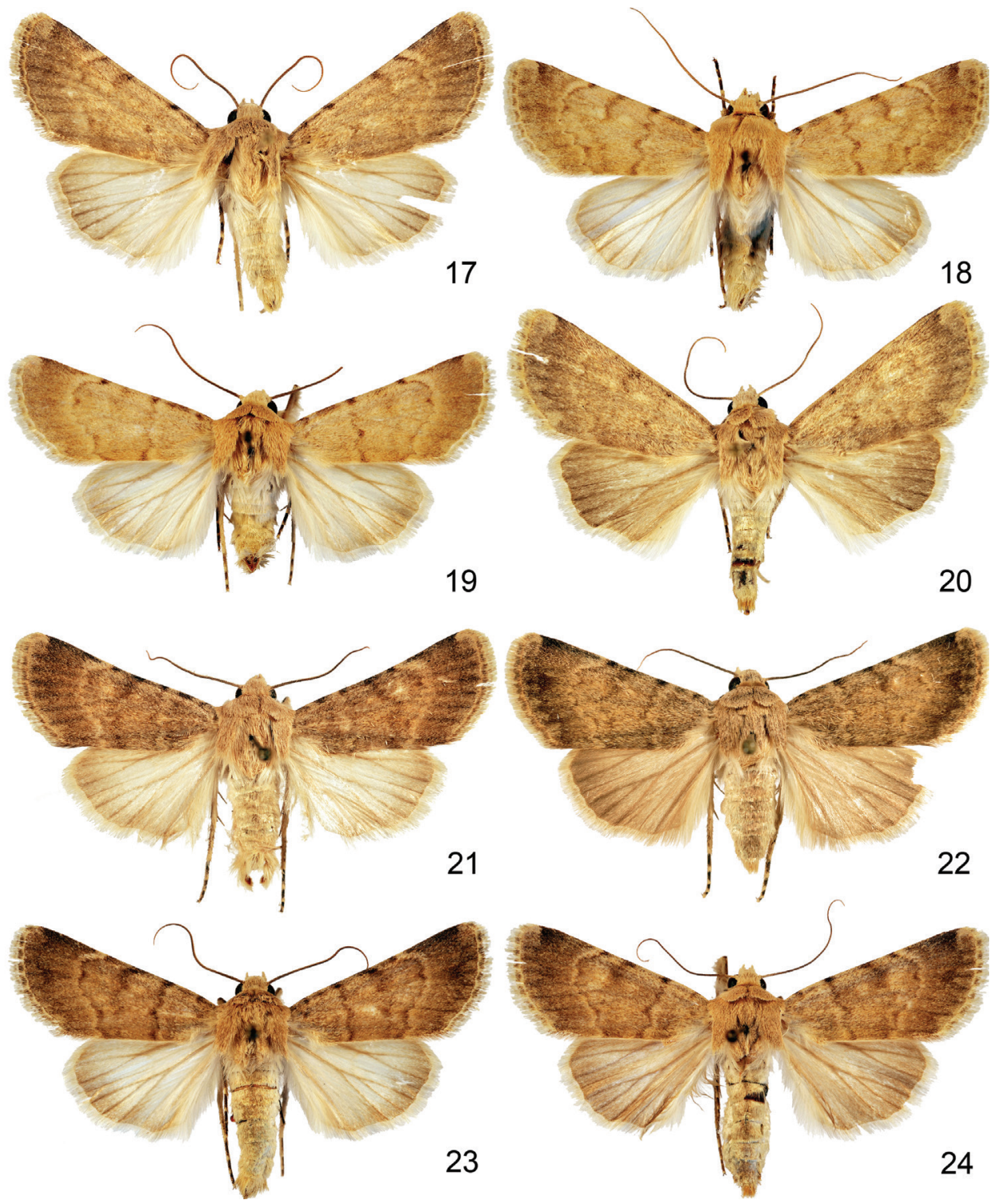

Figs 17-24. Dichagyris spp.: 17-20 = D. taftana elborsasta ssp. n., $17=$ holotype, male, Iran, Mazandaran, Elburz Mts, 18-19 = paratype males, Iran, Semnan, 20 = paratype, female, Iran, Mazandaran, Elburz Mts; 21-24=D. taftana safavida ssp. n., $21=$ paratype, male, Iran, Yazd, Qohrud Mt., 22 = paratype, female, Iran, Yazd, Qohrud Mt., 23 = paratype, male, Iran, $100 \mathrm{~km} \mathrm{~S}$ of Abadeh, 24 = paratype, female, Iran, $100 \mathrm{~km} \mathrm{~N}$ of Shiraz 

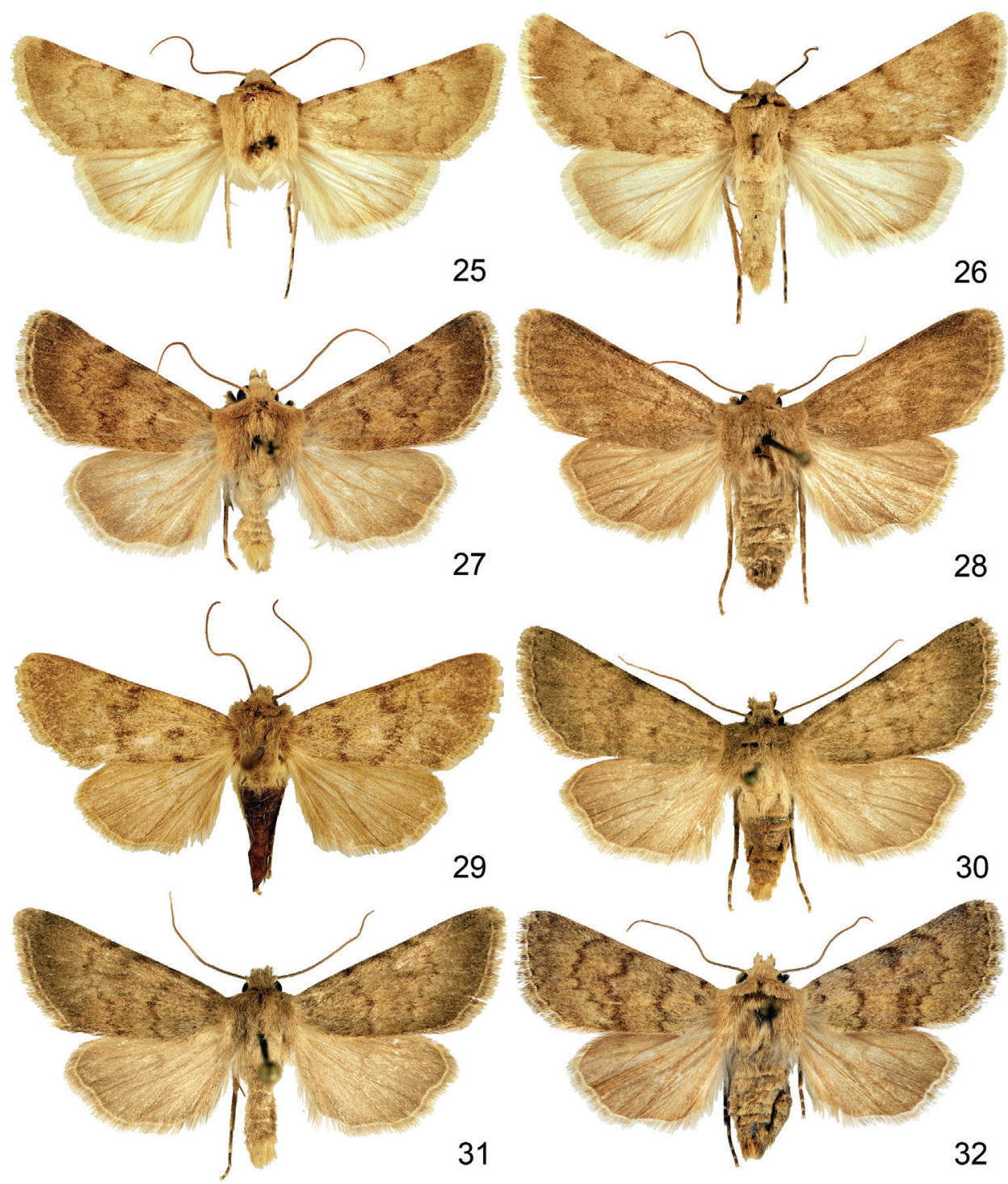

Figs 25-32. Dichagyris spp. 25-26= D. guentereberti sp. n., 25 = holotype, male, Afghanistan, Koh-i-Baba Mts, 26 = paratype, male, Afghanistan, Koh-i-Baba Mts; 27-28 = D. humilis (Boursin, 1940), 27 = male, Iran, Elburz Mts, Shemshak, 28 = male, Iran, Prov. Zanjan. Kuh-i-Sendan; 29-32 = D. hypotacta sp. n., $29=$ holotype, male, Afghanistan, Wakhan valley, 30-31 = paratype males, Pakistan, Hindukush Mts, Shandur Pass, 32 = paratype, female, Afghanistan, Paghman Mts, Salang Pass 
Taxonomy of the Dichagyris taftana group

with the description of a new species and two new subspecies

Dichagyris taftana Brandt, 1941 was described based on a long series of both sexes from the Koh-i-Taftan Mts (Iranian Baluchistan). The holotype and a part of the paratypes are deposited in the NRS; the other part of the paratypes was distributed in large European museums and private collections (e.g. NHMW, SMNK, ZSM). In the original description it was compared with $D$. terminicincta and D. humilis; these two species are, however, essentially smaller in size and are not closely related to $D$. taftana according to the structural traits of genitalia.

The typical subspecies taftana (Figs 15-16) is the largest among the disjunct populations of the species with its wingspan $37-40 \mathrm{~mm}$, and is characterised by the most contrasting forewing pattern. The light ochreous-brown to ochreous slate-grey ground colour of the head, thorax and forewings is only moderately suppressed by greyish-brown hairs and scales. The "noctuid" maculation is only faintly defined, the double crosslines are filled with darker greyish-brown colouration; the submarginal area is darker ochreousbrown with fine darker brown suffusion and 3-4 blurred arrowheads. The male hindwing is whitish with blurred greyish-brown marginal suffusion; the female hindwing is somewhat darker grey-brown irrorated, with light smoky-brown marginal field; cilia whitish.

According to the original description, the type series was collected at fairly high elevations (3000-3300 m). Unfortunately, no more recent material available. The populations of the Elburz and Zaghros mountain systems are geographically separated and taxonomically differentiated from the typical subspecies, while the more differentiated populations inhabiting the Afghan Hindukush represent a distinct species. These unnamed taxa are described below.

\section{Dichagyris taftana elborsasta ssp. $n$.}

(Figs 17-20, 45)

Holotype. Male, Iran, Prov. Mazandaran, Elburz Mts, Shahkuh-e-Bala, $2400 \mathrm{~m}$, N36³3', E54³6', 19.VII.2003, leg. G. Ebert \& R. Trusch; slide No. VZ9269m (coll. SMNK).

Paratypes. Iran. 2 males and 3 females, with same data as holotype (coll. SMNK); 1 male, Prov. Mazandaran, Elburz Mts, Shahkuh-e-Pain, 2750 m, N36 33', E54 266' (coll. SMNK); 3 males, 2 females, Shahrud area, Tash vil. vicinity, $2600 \mathrm{~m}, 36^{\circ} 34^{\prime} 42^{\prime \prime}$ N, E 54 $42^{\prime}$ 42”'E, 29-30. VI. 2010, leg. E. Gavristchuk (coll. M. Dvorak, Czech Rep.), 3 males with the same data (coll. H. Seibald, Austria), 1 male with the same data (coll. P. Gyulai, Miskolc, Hungary); 5 males, "N-Iran, Berge östl. Semnan, 18.VI.1963, leg. Kasy \& Vartian" (coll. NHMW). Slide Nos: GYP5555m, GYP5556m, VZ9270m, VZ10132m, VZ10133m, VZ9464f. 
Diagnosis. Generally smaller and more gracile than the typical ssp. taftana and the next new subspecies, ssp. safavida, with its wingspan 32-37 $\mathrm{mm}$. Light ochreous colouration of head, thorax and forewings strongly suppressed by reddish ochreous-brown hairs and scales; all forewing markings blurred; reniform and orbicular stigmata defined only by a few lighter ochreous spots; crosslines faint, submarginal field darker brown with some reddish
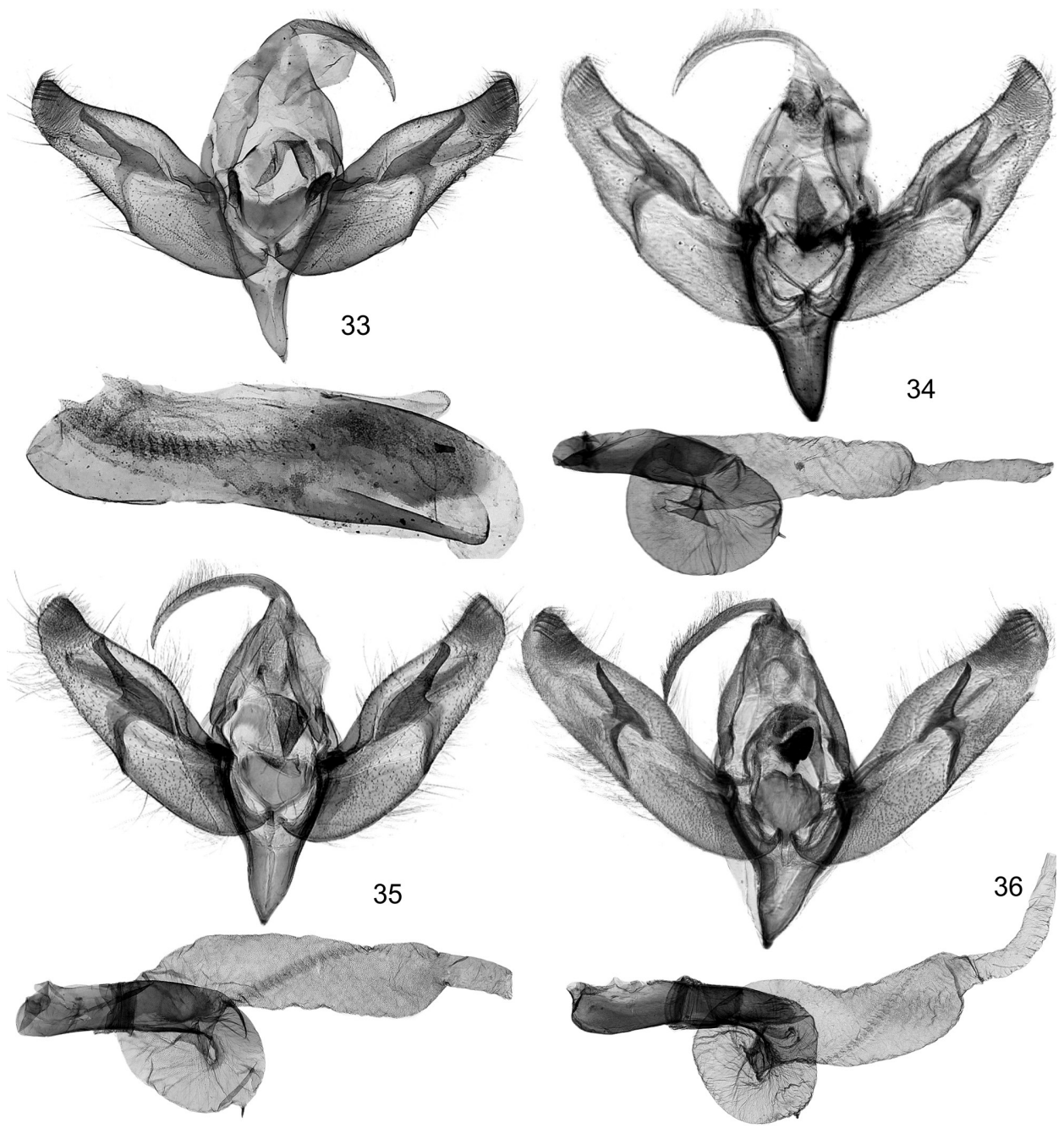

Figs 33-36. 33-35 = Male genitalia of Dichagyris vallesiaca taxa: $33=$ D. v. subsqualorum Kozhantshikov, 1930, Georgia, VZ1550m, 34 = D. v. venosa Kozhantshikov, 1930, Pamir, Khorog, VZ7741m, 35 = D. fuscashmiriana Varga, Ronkay et Ronkay, 2020, paratype, Pakistan, Kashmir, Deosai Mts, VZ9145m (clasping apparatus), VZ9143m (aedeagus), 36 = Male genitalia of Dichagyris griseotincta (Wagner, 1931), Turkey, Kayseri, Sultan Dagh, VZ9729m 
tint; hindwings in males whitish with diffuse, pale greyish marginal area; in females somewhat darker, light grey with fuscous marginal field.

Male genitalia (Fig. 45). The diagnostic features are the distally tapering valvae with robust, obtuse and terminally slightly dilated harpe (clasper),
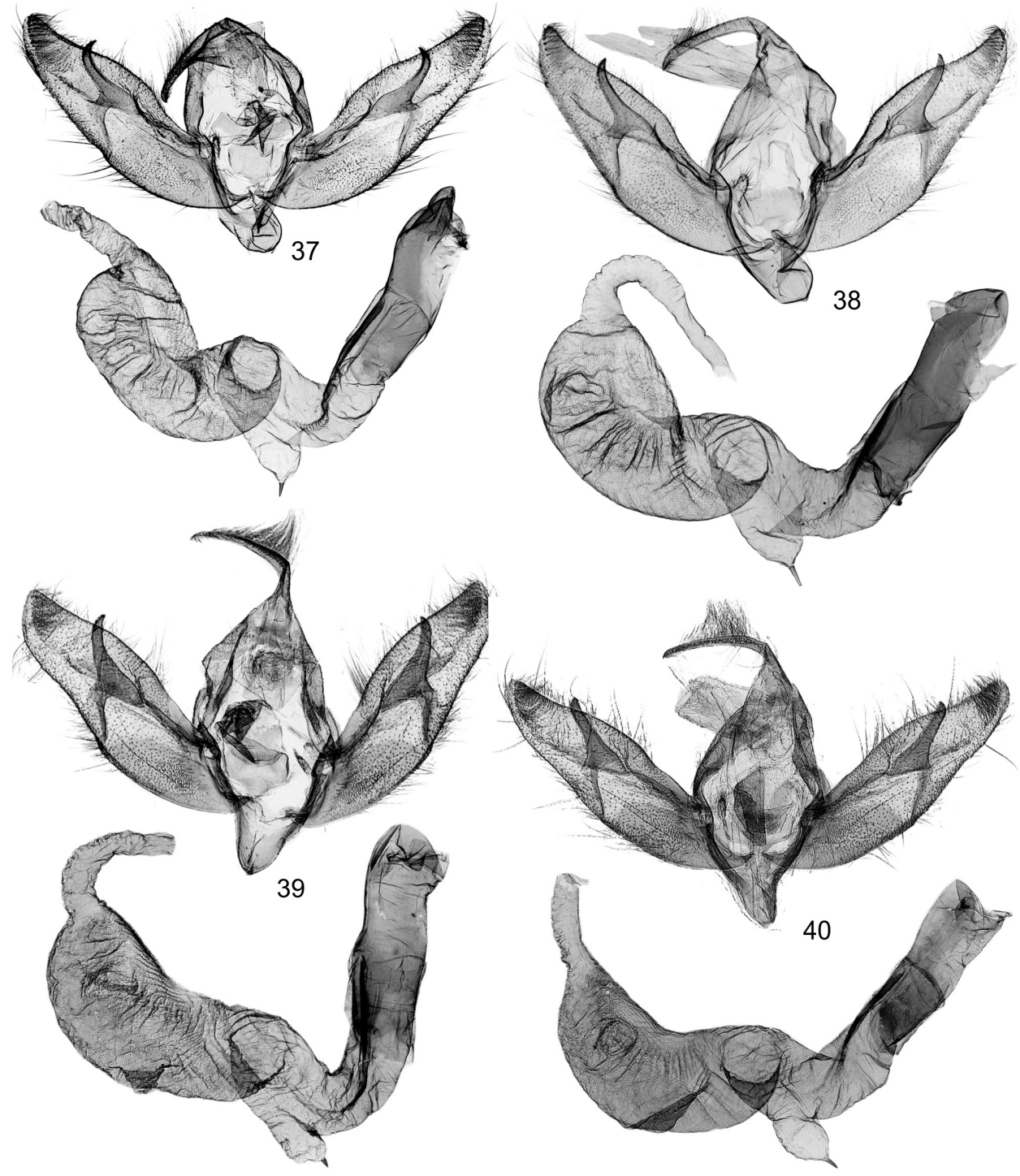

Figs 37-40. Male genitalia of Dichagyris spp.: $37=$ D. psammochroa psammochroa Boursin, 1940, Iran, Elburz Mts, VZ9320m; 38 = Dichagyris afghana Boursin, 1963, Afghanistan, Bandi-Amir, VZ8516m; 39-40 = Genitalia of Dichagyris kurbatskyi sp. n.: 39 = holotype, Kazakhstan, VZ10087m, 40 = paratype, Kazakhstan, VZ10094m 
and the subbasal diverticulum of the vesica is relatively larger than in the two other subspecies.

\section{Dichagyris taftana safavida ssp. $\mathrm{n}$.}

(Figs 21-24, 46)

Holotype. Male, Iran, Prov. Yazd, Mt. Qohrud, Ali Abad, 2000-2500 m, 27.V.1999, leg. T. Hácz \& G. Kószegi; slide No. GYP1399m (coll. P. Gyulai, later to be deposited in the HNHM).

Paratypes. Iran. Prov. Yazd. 2 males, 1 female, with same data as holotype (colls P. Gyulai, G. Ronkay, Z. Varga); 9 males, 1 female, Shīr Kūh Mts, 6 km NW of Taft-Aliabad, 2650 m, 10-11.VI.2005, leg. P. Gyulai \& A. Garai; 12 males, Kuhhá-ye-Qohrud, Mt Shīr Kūh, Sānij, 2650 m, N31³4,370', E5401,091', 14.VI.2007, leg. T. Hácz; 5 males, Qohrud Mts, Shīr Kūh, 2700 m, 14-15.VI.2007, leg. T. Hácz (coll. P. Gyulai). Prov. Esfahan. 2 males, Kuh-e-Karkas, 1700 m, 3 km SE of Natanz, 11-12.VI.2005, leg. P. Gyulai \& A. Garai (coll. P. Gyulai); 2 males, 1 female, N of Tarq, Kuh-e-Karkas, 2600 m, N33 $24^{\prime}$, E51 ${ }^{\circ} 48^{\prime}$, 7.VII.2003, G. Ebert \& R. Trusch leg. (coll. SMNK). South Iran. 2 males, 3 females, $100 \mathrm{~km} \mathrm{~S}$ of Abadeh, N of Didegan, 2000 m, 9.VI.1969, leg. Vartian (colls NHMW, Z. Varga).

Slide Nos: GYP5304m, VZ9317m, VZ10135m, VZ10185m.

Diagnosis. The populations occurring in the Iranian Provinces Yazd and Esfahan are on average slightly smaller (wingspan 36-38 $\mathrm{mm}$ ) and generally darker in colouration than those of the typical subspecies from Iranian Baluchistan (Mts Koh-i-Taftan). Head, collar, tegulae and forewings ochreous-brown, forewing with dense dark chocolate-brown irroration and fine reddish-brown tint; noctuid maculation faint; crosslines blurred; cilia brownish-ochreous with thin light ochreous basal line. Abdomen light greyishochreous. Hindwing whitish with blurred light brownish-grey marginal area. Sexes similar; females slightly darker, mostly at forewing submarginal field and more greyish hindwings.

The male genitalia of ssp. safavida (Fig. 46) can be distinguished from those of the other subspecies of $D$. taftana by the medially wider valvae, thicker and obliquely obtuse claspers, and by the more ample subbasal diverticulum with slightly longer, acute cornutus.

Bionomics and distribution. The range of the new subspecies is restricted to the Zaghros mountain system in Yazd and Esfahan provinces of Iran. It seems to have a rather local occurrence but with a relatively wide altitudinal distribution.

\section{Dichagyris guentereberti sp. $\mathrm{n}$.}

$$
\text { (Figs 25, 26, 47, 48) }
$$

Holotype. Male, Central Afghanistan, Koh-i-Baba Mts, southern side, Pandjao, 2560 m, 20-22.VII.1966, leg. G. Ebert; slide No. VZ8424m (coll. SMNK). 
Paratypes. Afghanistan. 1 male, with same data as holotype; 1 male, Central Afghanistan, Helmand, Mullah-Jacub-Pass, 3000 m, 16.VII.1966, leg. G. Ebert; 1 male, East Afghanistan, Salang-Pass, northern side (Khinjan), 2100 m, 5-11.VII.1966, leg. G. Ebert (coll. SMNK). Slide Nos VZ8517m, VZ9267m.

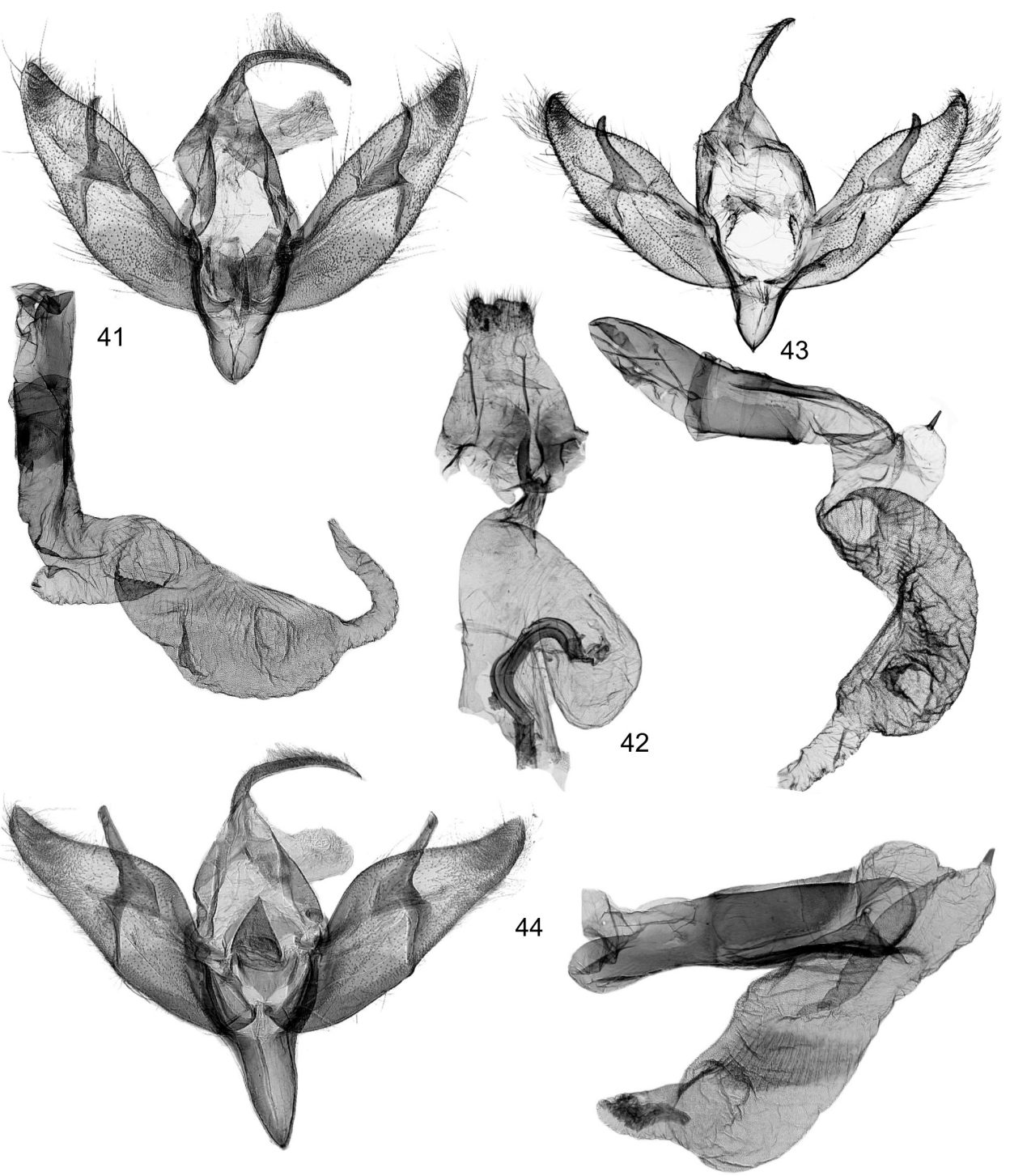

Figs 41-44. Genitalia of Dichagyris spp. 41-42 = D. kurbatskyi sp. n.: $41=$ paratype, Kazakhstan, VZ10095m, 42 = female, paratype, Kazakhstan, VZ10256f; 43 = D. psammochroa kopetdaghimena ssp. n., paratype, Turkmenistan, VZ9322m; $44=$ male genitalia of D. taftana taftana Brandt, 1941, paratype, Iran, Baluchistan, VZ9268m 
Diagnosis. The new species is on average slightly larger (wingspan 37-38 $\mathrm{mm}$ ) than its sister taxon $D$. taftana, having more elongate, apically more acute forewings. Collar and tegulae with diffuse darker margin, being generally much lighter than in any subspecies of $D$. taftana. Hindwings also much lighter than in $D$. taftana, whitish with diffuse light grey marginal area. The male
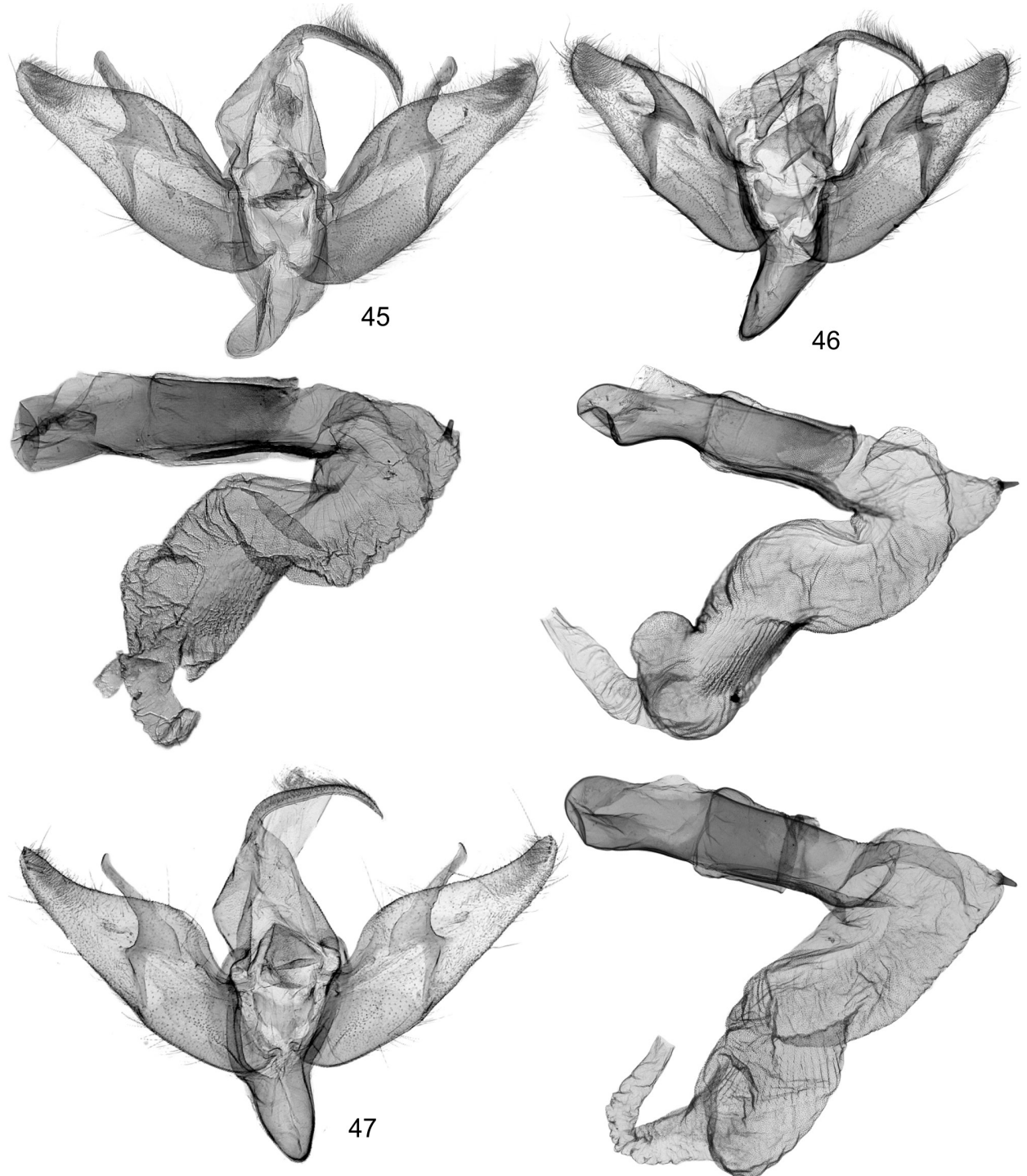

Figs 45-47. Male genitalia of Dichagyris spp. $45=$ D. taftana elborsasta ssp. n., paratype, Iran, Elburz, VZ9270m; $46=$ D. taftana safavida ssp. n. Iran, Kuh-e-Karkas, VZ10186m; $47=D$. guentereberti sp. n., holotype, Afghanistan, Central Hindukush Mts, VZ8424m 
genitalia of $D$. guentereberti differ from those of $D$. taftana by the more tapering distal part of valvae and the slenderer, apically more acute harpe (clasper).

Description. A relatively large species (37-38 mm) with rather elongate, apically acute narrow triangular forewings. Antennae finely ciliate, head light ochreous-grey. Thorax and forewings light greyish-ochreous, collar and tegulae with diffuse darker margin. Patterns of forewings generally faint, crosslines with dark brown patches on costa, antemedial line scattered, medial shadow diffuse, postmedial line crenulate; submarginal area with darker brownish suffusion; inner part of cilia light brownish-ochreous, outer part white. Hindwings silky whitish with diffuse light grey margin. Female unknown.

Male genitalia (Figs 47,48). The configuration of the genital capsule is as those of $D$. taftana but the valvae are more tapering distally, the harpe (clasper) is slenderer and more acute terminally, and the dorsal margin of juxta is concave. The vesica is also similar in the two species; the folded transversal stripe of D. guentereberti is less sclerotised than that of D. taftana.

Bionomics and distribution. The new species seems to be restricted to the central part of the Hindukush mountain system, from the Koh-i-Baba massif to the Salang pass. It must be extremely rare since only four specimens were found in the several thousands of Noctuidae moths collected in Afghanistan in the second half of the last century.

Etymology. The new species is gratefully dedicated to Mr. Günter Ebert, honoured expert in Lepidoptera research and conservation, and prominent researcher of the fauna of Afghanistan.

Remarks. One of the paratypes has teratological genitalia with malformed aedeagus and vesica.

\section{Taxonomy of the D. humilis group}

with the description of a new species and a new subspecies

Dichagyris humilis was described by Boursin (1940) based on a short but externally fairly diverse series of both sexes, collected in the central part of the Elburs mountains in 2000-3200 m altitudes. In the original description the relatively isolated status of this species was enhanced by some peculiar characters of male genitalia, as the reduction of the corona, the finely dentate, strong carina and the relatively long, needle-shaped cornutus of the vesica.

The externally somewhat different, lighter ochreous coloured specimens from the northern part of the Zaghros Mts (Prov. Hamadan, Mt. Alvend) were separated from the typical subspecies by Boursin in the same article as ssp. elvendi. Its taxonomic ranking seems, however, to be dubious, since the specimens collected in Prov. Zanjan, north of this region, cannot be differentiated from the typical subspecies. Moreover, specimens with yellowish coloura- 
tion occur also in the eastern part of the Elburz Mts (near Shahrud, Shahkuhe-Pa'in) while the specimens from the most northeastern province of Iran (Khorasan, Kuh-i-Binaloud) display a concolorous greyish-ochreous brown colouration with blurred pattern. All these externally slightly differentiated populations show, however, little variation in their genital characters, as opposed to the eastern sister species, described below.

\section{Dichagyris hypotacta $\mathrm{sp} . \mathrm{n}$.}

(Figs 29-32, 51-54)

Holotype. Male, Afghanistan, Wakhan, Kotal-e-Dalez, W slope, 3400 m, 27.VII.1971, leg. Ebert \& Naumann (SMNK).

Paratypes. Afghanistan. 145 males, 34 females, with same data as holotype (colls SMNK, NHMW, P. Gyulai, G. Ronkay, Z. Varga); 1 male, with same data, MHNG ENTO 20902, coll. J. Plante, MHNG); 33 males, 14 females, Wakhan, Darrah-e-Shaur, 3450 m, 25.VII.1971, leg. Ebert \& Naumann; 106 males, 7 females, Wakhan, Langar, 3500 m, 11.VII.1971, leg. Ebert \& Naumann; 4 males, 2 females, Wakhan, Sarhad, 3150 m, 8.VII.1971, leg. Ebert \& Naumann; 51 males, 14 females, Wakhan, Zamestani Baharak, 3300 m, 24.VII.1971, leg. Ebert \& Naumann (colls SMNK, NHMW, P. Gyulai, G. Ronkay, Z. Varga); 1 female, Paktia, 3500 m, Kotal-e-Sirkey, W side, 28.VI.-15.VII.1999, leg. S. Assad (coll. P. Gyulai); 42 males, 5 females, Koh-i-Baba Mts, Band-i-Amir, 3600 m, 27.IX.1963, leg. Kasy \& Vartian (colls NHMW, SMNK); 1 male, with same data, MHNG ENTO 20900, coll. Plante, MHNG); 1 male, Band-i-Amir, 2800 m, 9-12.VII.1975, leg. W. Thomas, MHNG ENTO 24100 (coll. J. Plante, MHNG); 37 males 8 females, Hazaradjat, Koh-i-Baba, Shatu-pass, 3000 m, 17-19.VII. 1966, leg. G. Ebert (coll. SMNK); 22 males, 5 females, Hazaradjat, Koh-i-Baba, Pandjao, 2650 m, 20-22.VII.1966, leg. G. Ebert (coll. SMNK); 1 male, with same data, MHNG ENTO 20899, coll. Plante, MHNG); 8 males, Paghman Mts, 20-30.VII.1962, 20-22.VII.1963, 1-15.VIII.1965, leg. E. \& A. Vartian (coll. NHMW); 1 male, 2 females, Badakhshan, Sarekanda, 4200 m, 31.VII.1953, leg. Klapperich (coll. ZSM), 1 male, with same data, with same data, MHNG ENTO 20898, coll. Plante, MHNG). Genital slide Nos VZ9332m, VZ10144m, VZ9444f. Tadjikistan. 2 males, W Pamir, Rushan, 3400 m, 20-30.VII.2001, leg. Gurko (coll. G. Ronkay, NHMW), 3 females, with same data (coll. HNHM); 1 male, 2 females, from the same locality, 1-10.VIII.2002, leg. Gurko (coll. G. Ronkay, NHMW); Gorno-Badakhshan: 4 males, 4 females, W-Pamir, Vantsh Mts, Rushan distr., 3400 m, 1-10.VIII.1992, leg. V. Gurko; 9 males, 10 females, the same locality and collector, 21-30.VII.1997 (colls. P. Gyulai, G. Ronkay); 14 males, 7 females, the same locality and collector, 1-10.VIII.1997; 6 males, the same locality and collector, 21-30.VIII.1997; 1 male, 1 female, the same locality and collector, 1-10.IX.1997; 2 males, 2 females, the same locality and collector, 10-20.VII.1998; 1 female, the same locality and collector, 1-10.VIII.1998; 5 males, 1 female, the same locality and collector, 11-20.VIII.1998; 1 male, 1 female, the same locality and collector, $3400 \mathrm{~m}, 1-10$. IX.1998; 1 male, 1 female, the same locality and collector, 11-20.VIII.1998; 1 male, the same locality and collector, 20-30.VIII.1998; 13 males, 20 females, the same locality and collector, 10-20.VII.2000; 14 males, 9 females, the same locality and collector, 20-30.VII.2001 (coll. P. Gyulai); 1 male, 3 females, W-Pamir, Sarez lake area, 3400 m, Irkift meteorological station, 20-30.VII.2011, 3400 m, leg. V. Gurko; 12 males, 24 females, the same locality and collector, 1-10.VIII.2011; 2 females, the same locality and collector, 10-20.VIII.2011 (coll. P. Gyulai); 1 female, E. Pamir, N. Tanimas range, Nature Reserve, middle stream of Shurali-Suu river, 
15-20.VII.2018, leg. D. Goshko; 4 males, E. Pamir, Sarykol Mts, 7457’'E, 37²40’ N, Oziornaja, 4300 m, 7.VIII.1994, leg. native collector; 3 males, E. Pamir, Sarykol Mts, Dunkeldik, 4300 m, 25-27.VII.1996, leg. Lukhtanov; 10 males, 3 females, Turkestan Mts, Shakhristan pass, Khushikat, 3100 m, 26-28.VII.1994, leg. Lukhtanov; 1 male, Seravshan basin, Turkestan Mts, 45 km E of Aini, Obburdon pass, 2800-3000 m, 13-15.VII.1994, leg. Lukhtanov; 5 males, 1 female, Seravshan Mts, Dasht, 68 $03^{\prime}$ E, 39²0’ N, 2600 m, 18-19.VII.1994, leg. Lukhtanov; 64 males, 86 females, SE Pamir Mts, Murgab distr., Ak-Bura massif; $20 \mathrm{~km} \mathrm{~W}$ of Tohtamish village, Sulu-istik river, 3900 m, 11-27.VII.2016, leg. D. Goshko; 8 males, 6 females, Pamir Mts, Murgab district, Sarykol Mt., r. Duljkenbik, 4000 m, 2-7.VIII.1994, leg. Titov; 1 male, 2 females, Pamir, Yuzhno-Alichurskiy range, Dzhilondy village, $3500 \mathrm{~m}$, near Irkift meteorological station, 29.VII.-3.VIII.2014, leg. D.A. Safronov; 1 female, Peter I. Mts, 14 km S

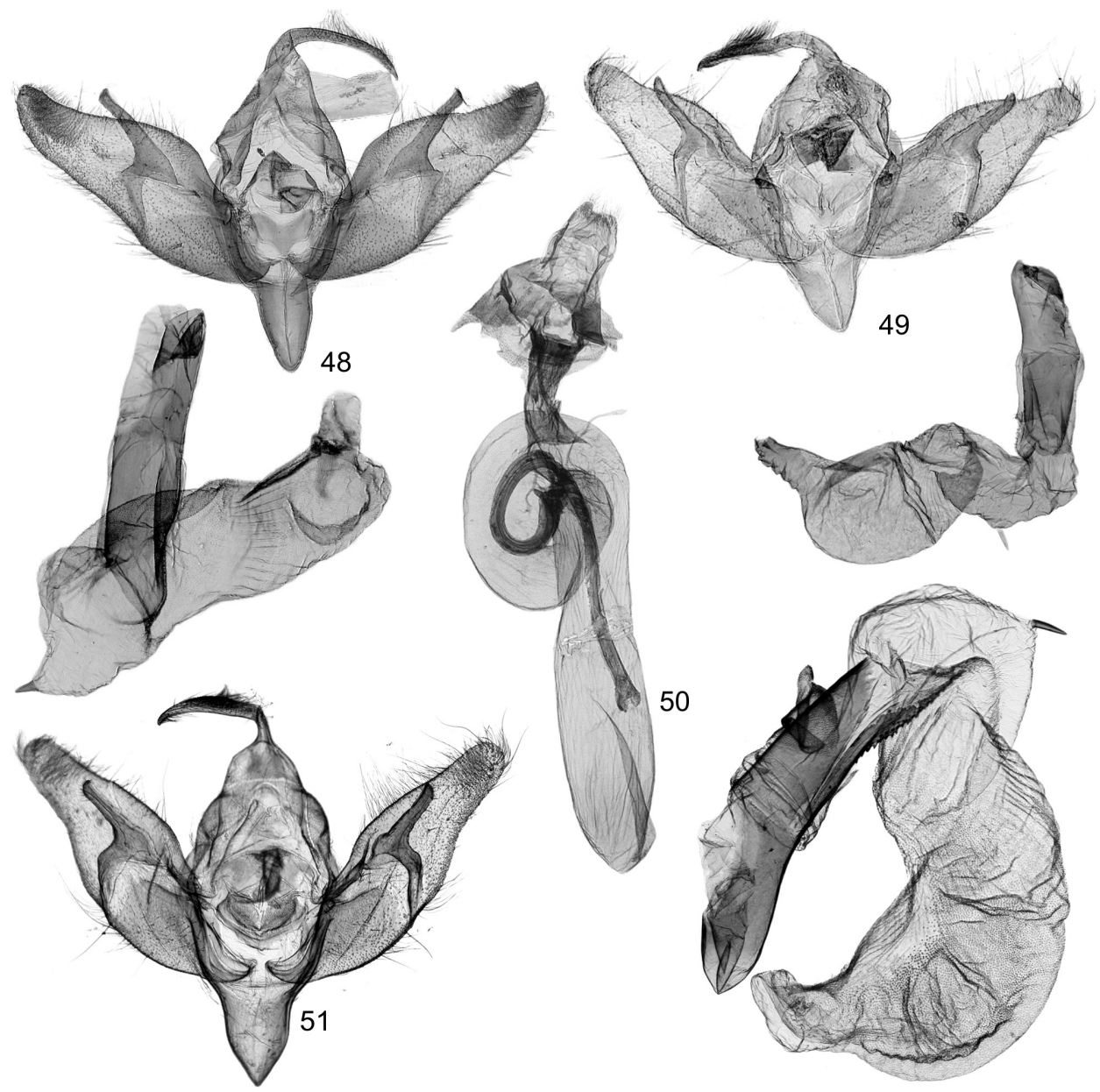

Figs 48-51. Genitalia of Dichagyris spp. $48=$ D. guentereberti sp. n., paratype, Afghanistan, Central Hindukush Mts, VZ9267m; 49-50 = D. humilis (Boursin, 1940). 49 = male, paratype, VZ7069m, 50 = female, paratype, VZ10072f; $51=$ D. hypotacta sp. n., male, paratype, Afghanistan, Wakhan, VZ9337m 
Tadjikabad, Tanis valley, 2180 m, 10.VIII.1977, leg. Yu. Shchetkin (coll. P. Gyulai). Genital slide Nos VZ10069m, VZ10069m, VZ10073f. Kirghisia. 1 female, Alai Mts, Tengizbai Pass, 10 km E of Daraut-Kurgan, 3000-3800 m, 11-25.VII.1995, leg. W. Lukhtanov (coll. G. Ronkay, NHMW). Pakistan. 56 males, 26 females, Hindukush Mts, 5 km E of Shandur Pass, 3500 m, 72³2’E, 36¹0’N , 13.VII.1994, leg. B. Herczig, Gy.M. László \& G. Ronkay; 12 males, 1 female, Hindukush Mts, Shandur Pass, 4300 m, 12.VII.1994, leg. B. Herczig, Gy.M. László \& G. Ronkay; 6 males, Hindukush Mts, Teru, 2500 m, 7240’E, 36¹4N, 14.VII.1994, leg. B. Herczig, Gy.M. László \& G. Ronkay (coll. G. Ronkay \& HNHM); 1 male, Hindukush Mts, 5 km E of Shandur Pass, 3300 m, 72³2’E, 36¹0’N, 30.VIII.1997, leg. Gy. Fábián \& G. Ronkay (coll. G. Ronkay); 24 males, 6 females, Hindukush Mts, $5 \mathrm{~km}$ SE of Shandur pass, $3250 \mathrm{~m}$, $72^{\circ} 38^{\prime} \mathrm{E}, 36^{\circ} 07^{\prime} \mathrm{N}, 11 . \mathrm{VIII} .1998$, leg. G. Ronkay \& Z. Varga (colls G. Ronkay, Z. Varga); 17 males, 5 females, Hindukush Mts, $5 \mathrm{~km}$ E of Shandur pass, $3750 \mathrm{~m}, 72^{\circ} 38^{\prime} \mathrm{E}, 36^{\circ} 07^{\prime} \mathrm{N}, 26-27$. VI.2000, leg. G. Ronkay \& Z. Varga (colls G. Ronkay, Z. Varga); 6 males, 1 female, Hindukush Mts, Teru, 2500 m, 72 $40^{\prime}$ E, 36 $36^{\circ}{ }^{\prime}$ N, 28.VI.2000, leg. G. Ronkay \& Z. Varga (colls G. Ronkay, Z. Varga); 1 female, Hindukush Mts, $5 \mathrm{~km}$ E of Shandur pass, $3250 \mathrm{~m}, 72^{\circ} 38^{\prime} \mathrm{E}$, $36^{\circ} 07^{\prime} \mathrm{N}$, 23.VIII.2001, leg. G. Ronkay (coll. HNHM); 1 male, 2 females, Hindukush Mts, 5 $\mathrm{km}$ E of Shandur pass, 3350 m, 23.VII.2011, leg. B. Benedek (coll. P. Gyulai); 18 males, 17

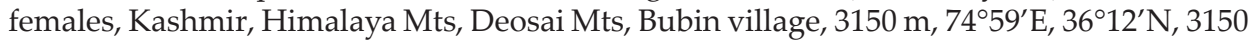
m, 12.VIII.1998, leg. G. Ronkay \& Z. Varga (colls G. Ronkay, Z. Varga), 1 male, Gilgit, road to Khunjerab Pass, Sost, 2775 m, 19-20.VII.1990, leg. Aulombard \& Plante, MHNG ENTO 20901 (coll. Plante, MHNG). ). Genital slide Nos VZ7067m, VZ8019m, VZ8037m, VZ9337m, VZ9446, VZ9853m, VZ10288m, VZ10067f. India, Jammu \& Kashmir. 1 female, Fatu-LaPass, 3800 m, 28-29.VII.1980, leg. W. Thomas, MHNG ENTO 16173 (coll. Plante, MHNG).

Diagnosis. The new species is the eastern sister species of the Iranian D. humilis. Dichagyris hypotacta is very similar externally to D. humilis (Figs 27-28) but somewhat larger in size (wingspan 31-33 mm, the measures of the two species are slightly overlapping); the forewing is more acute apically and more concolorous due to the more intense dark brownish irroration; all forewing markings are less expressed than in $D$. humilis.

The male genitalia (Figs 51-53) are generally similar to those of D. humilis (Fig 49) but the uncus of the new species is slightly slenderer than that of $D$. humilis, the valvae are more tapering distally, the aedeagus is somewhat longer, with slenderer dentate bar of the sclerotised carina, and the cornutus on the short subbasal diverticulum is directed more ventrally.

The female genitalia of the two species are generally similar but the papillae of ovipositor of D. hypotacta (Fig. 54) are less quadratic than in D. humilis (Fig. 50), the antrum is narrower, not funnel-shaped, the ductus bursae is slightly shorter and more wrinkled longitudinally, and the appendix bursae is less globular than those of D. humilis.

Description. Wingspan 31-33 mm. Head and thorax varies from dark fuscous to ochreous-brown, with considerable individual and/or local variation. Forewings acute triangular with elongate apex; ground colour dull fuscous, greyish-brown or ochreousbrown, with remarkable variation in shade (most probably due to the substrate of the habitat: pale ochreous-brown in certain parts of the Central Hindukush, e.g. Band-i-Amir; dark 
greyish-brown in most parts of Tadjikistan and Pakistan). Noctuid maculation usually blurred, marked only by a few darker brownish-grey scales; antemedial and postmedial crosslines and median fascia slightly darker than ground colour. Submarginal area somewhat darker; subterminal line obsolete; inner part of cilia fuscous, outer part light ochreous. Hindwing ochreous-brown with diffuse darker marginal area and light ochreous cilia. Sexes similar, the females are on average smaller and slightly darker than the males.

Male genitalia. The configuration is identical with the general type of Dichagyris; uncus acute, elongate falcate, valvae distally tapering, corona reduced; harpe strong, nearly straight, surpassing costal margin. Carina strongly sclerotised, dentate; vesica saccate, semi-helicoidal with ample subbasal diverticulum bearing a ventrally directed needleshaped cornutus.

Female genitalia. Ovipositor short, weakly sclerotised; antrum bilaterally slightly sclerotised, ductus bursae longitudinally wrinkled; corpus bursae elongate, saccate terminally; appendix bursae rounded tetragonal.

Taxonomic note. This species was already figured by CoRTI in the Supplement of Palaearctic Noctuidae III (1933; Plate 9, Fig. g) under the in litteris name gregalis. This name was mentioned in the text, however, without any description or diagnosis, as erroneously synonymised with "Episilia" (= Xestia s.l.) proterva Püngeler, 1904. Therefore, the name gregalis cannot be used for this species.
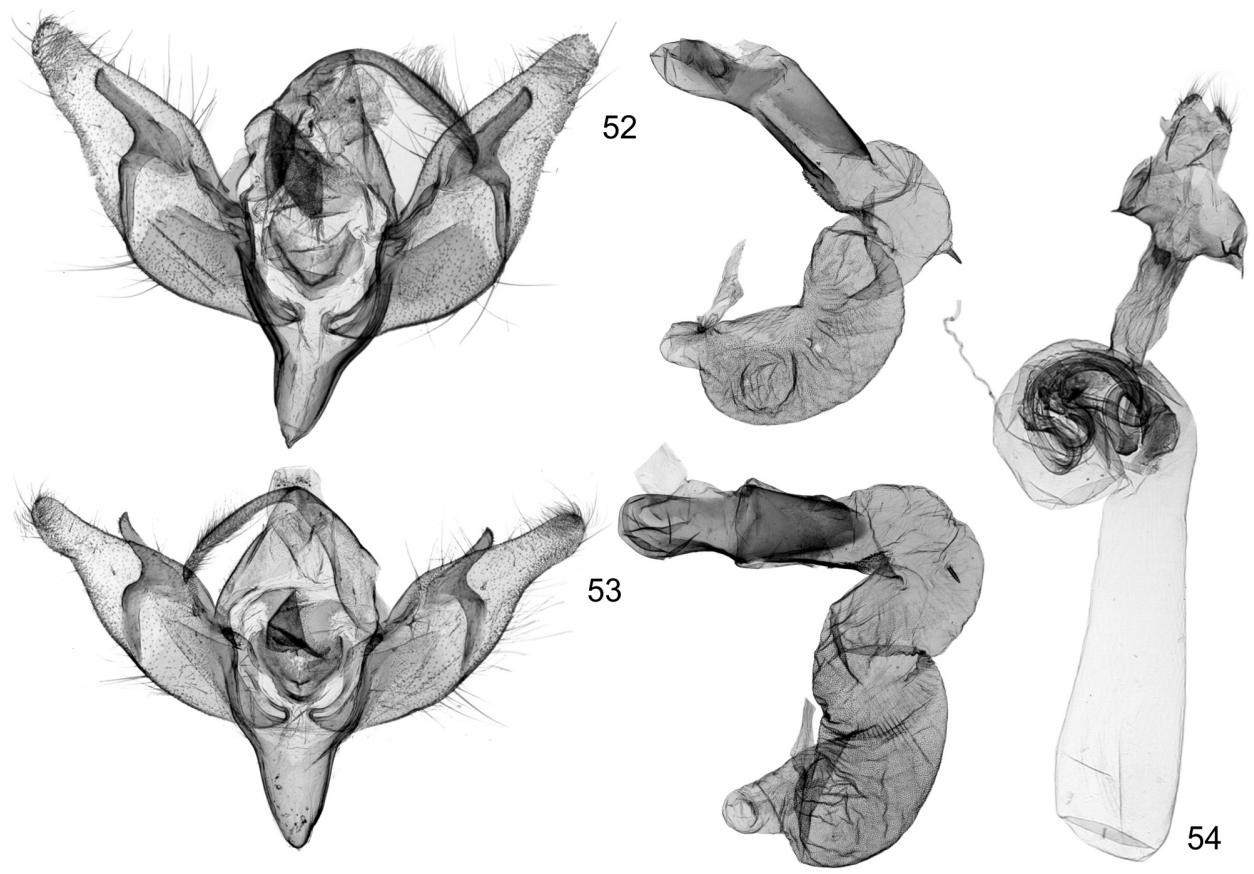

Figs 52-54. Genitalia of Dichagyris hypotacta sp. n., paratypes: 52-53 = males, Tadjikistan, Murgab, VZ10069m, 53 = Pakistan, Shandur Pass, VZ10067m, 54 = female, Tadjikistan, Murgab, VZ10073f 
Bionomics and distribution. Dichagyris hypotacta is the eastern allopatric sibling of $D$. humilis with wide distribution in the Eastern Tien Shan, the Pamirs, the Hindukush and the Western Himalayas mountain systems. It often belongs to the dominant Noctuinae species in high altitudes.

Etymology. Hypotacta (Greek) means subordinated, nearly synonymous with the meaning of the Latin humilis.

\section{DISCUSSION AND CONCLUSIONS}

It is generally accepted that the highly diverse Holarctic genus Dichagyris, containing about 170 species, is subdivided into several subgenera (FIBIGER 1997, Fibiger \& Lafontaine 1997, 2005, Lafontaine 2004). Most of them are exclusively Palaearctic, as the most species-rich subgenus Dichagyris which consists only in the western Palaearctic at least nine species groups (FIBIGER 1997). Core area of species diversity of this subgenus is extending from East of the Anatolian Diagonal to the Tien Shan, Hindukush and Pamirs mountain systems in western Central Asia. Surprisingly, Dichagyris s. str. is relatively poorly represented in the Sino-Himalayan region.

Cumulative occurrence of endemic species and/or subspecies was found in Transcaspia (Kopet-Dagh and Binaloud Mts), in different parts of the Tien Shan system, in the Hissaro-Darwaz area and western Pamirs, in the Central Hindukush (Koh-i-Baba massif) and in the eastern part of the Hindukush range connected with the western Himalaya. Moreover, all of the species groups of Dichagyris (s. str.) co-occur in these mountains, often represented by numerous sympatric species. Some of them are widely distributed mountain steppic species, subdivided to several subspecies, as D. leucomelas, D. vallesiaca, D. nigrolineata (=squalorum auct. nec Eversmann), D. celebrata, D. terminicincta, D. candelisequa.

The Irano-Transcaspian mountains vs the Central Asiatic massifs of the Tien-Shan and Hindukush systems are characterised by some pairs of sister species, as D. squalidior and D. payotiorum, D. striata and D. tyrannus, D. psammochroa and D. afghana, or D. humilis and D. hypotacta. These allopatric siblings are separated by typical long-distance Transcaspian-Central Asiatic disjunction. Completely parallel cases of vicariance were already shown in the not closely related but ecologically rather similar genus Chersotis (VARGA 1996, VARGA et al. 2013). In other cases the splitting of the sister species has been proceeded at the eastern periphery of range of the extended sibling, as $D$. vallesiaca versus $D$. fuscashmiriana, $D$. verecunda vs $D$. karakorealis, $D$. singularis vs D. melanofusca (Ronkay et al. 2020).

The genus has a western monophyletic clade, i.e. the melanura-group with two main species groups: the melanura-group with bulbed cornutus on 
the subbasal diverticulum of vesica is focused to the East-Mediterranean area, as opposed to the more Western and Central Asiatic leucomelas-group with a simple short cornutus in homologous position, and with an isolated TransMediterranean deserticolous species, $D$. imperator. Another, principally West Palaearctic species group is the D. forficula-group, distributed from the East Mediterranean area to the Western Tien Shan and Hindukush ranges, with one widely distributed polytypic species $(D$. forficula with several substrate dependent colour variations), and several, structurally only weakly differentiated closely related species with limited ranges $(D$. erubescens, $D$. contermina, D. turana, incl. D. turana furiosa).

The most species-rich group is the principally West Palaearctic vallesiacagroup, with obvious trend of allopatric speciation, see the "quasi-superspecies" D. vallesiaca (on the subdivision see: Kozhantshiкov 1930, 1937) along its nearly Trans-Palaearctic range from the Western Alps to the Govi Altai chains in Mongolia. The co-occurrence of the species belonging to the same species group is only typical for these three species groups in some West Palaearctic areas as in Central and Eastern Anatolia (D. melanura, D. grisescens, D. leucomelas; D. vallesiaca, D. griseotincta, D. nigrolineata, D. squalidior, D. eremicola; D. forficula, D. erubescens, D. contermina), in the Elburz and Kopet-Dagh ranges in Iran (adding D. korshunovi, D. forficula devota and D. striata), or in western part of the Tien Shan and also of the Hindukush system in Afghanistan, including the Paghman Mts (with further species as D. melanuroides, D. stellans, D. tyrannus, or D. turana).

Another distinct species group of the subgenus consists of species related with D. umbrifera, showing the highest number of species in the TranscaspianIranian area, with outposts on one side in Eastern Anatolia and Transcaucasia (D. achtalensis), and Mongolia on the other (D. kaszabi). In the steppes and semi-deserts near to the Southern Urals, and also in the Altai range only occur some geographically isolated species, as D. duskei, D. lux, D. kirghisa, and D. korsak on one hand, and D. kaszabi, D. ignara on the other. As opposed to these species with restricted range, there are several widely distributed, often polytypic species which are extended into the zonal steppe belt of South-Eastern Europe, as D. vallesiaca squalorum, D. nigrolineata, D. truculenta, D. flavina. This trend, however, already has been observed in more, ecologically similar genera in both tribes of Noctuinae, as Actebia s. 1. on one hand, and Chersotis, Rhyacia, Eugnorisma on the other (VARGA et al. 2013, 2015).

Last but not least, Albocosta Fibiger et Lafontaine, 1997, described and often considered as a distinct genus, should also be allied to Dichagyris, as a subgenus, consisting of two different phyletic lines. The species belonging to the first line, including the type species of the genus, $D$. (A.) musiva, share an elongate, basally more or less inflated tubular shape of the vesica, with subbasal diverticulum armed with a fine, acute cornutus and regularly also with 
a wart-shaped subterminal diverticulum. This lineage comprises the taxa of the musiva, juldussi and ulrici species groups. The other phyletic line is characterised by a helicoidal retroflexion of the vesica and a more medially translocated short diverticulum bearing cornutus. The female genitalia of both large groups have almost equally long, sacculiform corpus bursae and appendix bursae, and weakly sclerotized and relatively narrow ductus bursae but the sclerotization of the antrum is thinner, stripe-like in the first group, while it is elliptical or cordiform in the second group.

The two main lineages of the subgenus represent different biogeographical components in the Palaearctic region. The species of the "tubular vesica" lineage are generally connected to high montane and/or mountain steppic habitats, and they show the highest species diversity in the Central Asiatic semiarid mountains as the Pamirs, the Tien Shan system and the mountains near to the Tibetan plateau. Oppositely, the members of the group having ",retroflexed vesica" are typical Sino-Himalayan faunal elements, with six generally accepted and probably certain additional cryptic species. The checklist and taxonomic revision of these species groups will be published in a separate paper.

$*$

Acknowledgements - The authors are grateful to Péter Gyulai (Miskolc, Hungary), Robert Trusch and Michael Falkenberg (Landessammlungen für Naturkunde, Karlsruhe), Bert Gustafsson and Tobias Malm (Naturhistoriska Riksmuseet, Stockholm), Bernard Landry (Museum d'Histoire Naturelle,Genève), Clas M. Naumann (†), Dieter Stüning (Zoological Research Museum Alexander Koenig, Bonn), Sabine Gaal-Haszler and Martin Lödl (Naturhistorisches Museum, Vienna), Axel Hausmann and Ulf Buchsbaum (Zoologische Staatssammlung, Munich), Wolfram Mey (Museum für Naturkunde, Berlin), Martin Honey and Alberto Zilli (The Natural History Museum, London), for the possibility of study valuable collection materials, including types.

We are indebted to Lórántné Csenkey (HNHM, Budapest), Ádám Kiss (HNHM, Gyöngyös) and Péter Kozma (University of Debrecen) for technical assistance. Present survey was financially supported by the K116694 grant of NKFI-OTKA and OTKA T16465 (Z. Varga) and by the SYNTHESYS Project (European Community Research Infrastructure Action FP6 "Structuring the European Research Area" Programme) Grants Nos: NL-TAF 3007, DE-TAF-6708 (Z. Varga); GBTAF-2644, DE-TAF-3514, AT-TAF-5609 (G. Ronkay); GBTAF-2656, FR-TAF-562 and SETAF-6919 (Stockholm) (L. Ronkay).

\section{REFERENCES}

Boursin, Сн. (1940): Beiträge zur Kenntnis der Agrotidae-Trifinae XXIII. Neue palaearktische Arten und Formen mit besonderer Berücksichtigung der Gattung Autophila Hb. - Mitteilungen der Münchner Entomologische Gesellschaft 30: 474-543.

Boursin, Сн. (1963): Nouvelles races de Noctuidae paléarctiques (Lép. Noctuidae). - Bulletin mensuel de la Societé Linnéenne de Lyon 32(9): 254-262.

https://doi.org/10.3406/linly.1963.7176 
Brandt, W. (1938): Beitrag zur Lepidopteren-fauna von Iran. - Entomologische Rundschau 55: $1-72$.

BRANDT, W. (1941): Beitrag zur Lepidopteren-Fauna von Iran (3). Neue Agrotiden nebst Faunenverzeichnissen. - Mitteilungen der Münchner Entomologische Gesellschaft 31: 835-863.

Corti, A. \& Draudt, M. (1933): Rhyacia. In: Seitz, A. (ed.): The Macrolepidoptera of the World. Supplement to Volume 3. The Palaearctic noctuid moths. - Alfred Kernen Verlag, Stuttgart, p. 68.

Ebert, G. \& Hacker, H. H. (2002): Beitrag zur Fauna der Noctuidae des Iran: Verzeichnis der bestande im staatlichen Museum für Naturkunde Karlsruhe, taxonomische Bemerkungen und beschreibung neuer Taxa. - Esperiana 9: 237-409.

Fibiger, M. (1990): Noctuinae I. - Noctuidae Europaeae. Vol. 1. - Entomological Press, Sorø, 208 pp.

Fibiger, M. (1997): Noctuinae III. - Noctuidae Europaeae. Vol. 3. - Entomological Press, Sorø, $230 \mathrm{pp}$.

Fibiger, M. \& Lafontaine, J. D. (2005): A review of the higher classification of the Noctuoidea (Lepidoptera) with special reference to the Holarctic Fauna. - Esperiana 11: 7-92.

Gyulai, P. \& Ronkay, L. (2006): New Noctuidae taxa from Iran and Turkey (Lepidoptera). - Esperiana 12: 255-266.

Gyulai, P. \& VArga, Z. (2006): New taxa of Noctuidae, Noctuinae from Iran and Central Asia (Lepidoptera). - Esperiana 12: 271-181.

HACKer, H. (1990): Die Noctuidae Vorderasiens (Lepidoptera). Systematische List mit einer Übersicht über die Verbreitung unter besondere Berücksichtigung der fauna der Türkei (einschließlich der Nachbargebiete Balkan, Südrußland, Westturkestan, Arabische Halbinsel, Ägypten). - Neue Entomologische Nachrichten 27: 1-707, 16 Taf.

Hacker, H. \& Kautt, P. (1999): Noctuoidea aus dem Iran, gesammelt 1997 von A. Hofmann und P. Kautt (Insecta, Lepidoptera). - Esperiana 7: 473-484.

Hampson, G. F. 1898-1913. Catalogue of the Lepidoptera Phalaenae in the British Museum, Vols 1-13. - British Museum Natural History, London. https://doi.org/10.5962/bhl.title.52217

Kоzналтsнiкоv, I. V. (1930): Übersicht der Gattung Dichagyris Ld. (Lepidoptera, Noctuidae). - Entomologicheskoe Obozrenie 24: 1-30.

Kozhantshikov, I. V. (1937): Faune de l'URSS, Insectes Lepidopteres, fam. Noctuidae, subfam. Agrotinae. - Academia Scientiarum de l'URSS, Moscow-Leningrad. [In Russian]

Lafontaine, J. D. (1987): Noctuoidea: Noctuidae (part): Noctuinae (Part Euxoa). In: DominIck, R. B. et al. (eds): The moths of North America. Fascicle 27.2. - The Wedge Entomological Research Foundation, Washington, 237 pp.

Lafontaine, J. D. (1998): Noctuoidea; Noctuidae (part). In: Hodges, R. W. (ed.): The moths of America North of Mexico. Fascicle 27.3. - The Wedge Entomological Research Foundation, Washington, $348 \mathrm{pp}$.

Lafontaine, J. D. (2004): Noctuoidea: Noctuidae (part) - Agrotini. In: Hodges, R. W. (ed.): The moths of America North of Mexico. Fascicle 27.1. - The Wedge Entomological Research Foundation, Washington, $394 \mathrm{pp}$.

Lafontaine, J. D. \& Fibiger, M (2006): Revised higher classification of the Noctuoidea (Lepidoptera). - The Canadian Entomologist 138: 610-635. https://doi.org/10.4039/n06-012

Lafontaine, J. D. \& Schmidt, C. (2010): Annotated check list of the Noctuoidea (Insecta, Lepidoptera) of North America North of Mexico. - Zookeys 40: 1-239. https://doi.org/10.3897/zookeys.40.414 
Mitchell, A., Mitter, C. \& Regier, J. C. (2006): Systematics and evolution of the cutworm moths (Lepidoptera: Noctuidae): evidence from two protein-coding nuclear genes. Systematic Entomology 31: 21-46. https://doi.org/10.1111/j.1365-3113.2005.00306.x

Regier, J. C., Mitter, C., Mitter, K., Cummings, M. P., Bazinet, A. L., Hallwachs, W., JANZEN, D. H. \& Zwick, A. (2016): Further progress on the phylogeny of Noctuoidea (Insecta: Lepidoptera) using an expanded gene sample. - Systematic Entomology 42(1): 82-93. https://doi.org/10.1111/syen.12199

Robinson, G. S. (1976): The preparation of slides of Lepidoptera genitalia with special reference to the Microlepidoptera. - Entomologist's Gazette 27: 127-132.

Ronkay, L. \& Gyulai, P. (2006): New Noctuidae (Lepidoptera) species from Iran and Tibet. - Esperiana 12: 211-241.

Staudinger, O. \& Wocke, M. (1871) Catalog der Lepidopteren des Europäischen Faunengebiets. - Verlag O. Staudinger, Dresden, 426 pp.

VArga, Z. (1993): Beiträge zur Kenntnis der Gattung Dichagyris Lederer, 1857 (Lep.: Noctuidae) I. - Acta Zoologica Academiae Scientiarum Hungaricae 39: 289-300.

VARGA, Z. (1996): New species and subspecies of Dichagyris, Chersotis and Rhyacia (Noctuidae, subfam. Noctuinae) from Central Asia. - Acta Zoologica Academiae Scientiarum Hungaricae 42(3): 195-230.

Varga, Z., Gyulai, P. \& Miatleuski, J. (2002): New species of Noctuidae, Noctuinae from Iran and Central Asia. - Esperiana 9: 207-225.

Varga, Z., Gyulai, P., Ronkay, G. \& Ronkay, L. (2013): Noctuinae I. A taxonomic atlas of the Eurasian and North African Noctuoidea. The Witt Catalogue, Vol. 6. - Heterocera Press, Budapest, 313 pp.

Varga, Z., Gyulai, P., Ronkay, G. \& Ronkay, L. (2015): Noctuinae II. A taxonomic atlas of the Eurasian and North African Noctuoidea. The Witt Catalogue, Vol. 8. - Heterocera Press, Budapest, $362 \mathrm{pp}$.

Zahiri, R., Kitching, I. J., Lafontaine, J. D., Mutanen, M., Kaila, L., Holloway, J. D. \& WAHLBERG, N. (2011): A new molecular phylogeny offers hope for a stable familylevel classification of the Noctuoidea (Lepidoptera). - Zoologica Scripta 40(2): 158-173. https://doi.org/10.1111/j.1463-6409.2010.00459.x

Zahiri, R., Lafontaine, J. D., Schmidt, C., Holloway, J. D. Kitching, I. J., Mutanen, M. \& WAHLBERG, N. (2013): Relationships among the basal lineages of Noctuidae (Lepidoptera, Noctuoidea) based on eight gene regions. - Zoologica Scripta 42: 488-507. https://doi.org/10.1111/zsc.12022

Received, 2020, accepted August 19, 2021, published November 19, 2021

\section{APPENDIX}

Taxonomy of Dichagyris species mentioned in the publication
D. (Dichagyris) melanura (Kollar, 1846)
D. (Dichagyris) korshunovi Varga, 1996
D. (Dichagyris) grisescens Staudinger, 1878
D. (Dichagyris) leucomelas Brandt, 1941
D. (Dichagyris) melanuroides Kozhantshikov, 1930
D. (Dichagyris) stellans (Corti et Draudt, 1933)
D. (Dichagyris) duskei Moberg et Fibiger, 1990 
D. (Dichagyris) imperator (A. Bang-Haas, 1912)

D. (Dichagyris) vallesiaca vallesiaca (Boisduval, 1837)

D. (Dichagyris) vallesiaca crymaea Kozhantshikov, 1930

D. (Dichagyris) vallesiaca squalorum (Eversmann, 1856) comb. nov.

D. (Dichagyris) vallesiaca subsqualorum Kozhantshikov, 1930

D. (Dichagyris) vallesiaca inexpectata Kozhantshikov, 1925

D. (Dichagyris) vallesiaca venosa Corti et Draudt, 1933

D. (Dichagyris) fuscashmiriana Varga, Ronkay et Ronkay, 2020

D. (Dichagyris) griseotincta (Wagner, 1931)

D. (Dichagyris) tyrannus (A. Bang-Haas, 1912)

D. (Dichagyris) striata striata Kozhantshikov, 1930

D. (Dichagyris) striata beluchus Brandt, 1941

D. (Dichagyris) nigrolineata Kozhantshikov, 1930 (= squalorum sensu Boursin)

D. (Dichagyris) eremicola (Standfuss, 1888)

D. (Dichagyris) kirghisa (Eversmann, 1856)

D. (Dichagyris) squalidior (Staudinger, 1901)

D. (Dichagyris) lux Fibiger et Nupponen, 2002

D. (Dichagyris) payotiorum Varga, Ronkay et Ronkay

D. (Dichagyris) umbrifera (Alphéraky, 1882)

D. (Dichagyris) kaszabi Varga, 1973

D. (Dichagyris) naumanni Varga, 1996

D. (Dichagyris) jacobsoni Kozhantshikov, 1930

D. (Dichagyris) herzi (Kozhantshikov, 1930)

D. (Dichagyris) korsak Varga, Gyulai et Miatleuski 2002

D. (Dichagyris) achtalensis (Kozhantshikov, 1929)

D. (Dichagyris) cataleipa Varga, 1993

D. (Dichagyris) psammochroa psammochroa (Boursin, 1940)

D. (Dichagyris) psammochroa kopetdaghimena Varga, Ronkay et Ronkay sp. n.

D. (Dichagyris) afghana Boursin, 1963

D. (Dichagyris) apochora Gyulai et Varga, 2001

D. (Dichagyris) kurbatskyi Varga, Ronkay et Ronkay sp. n.

D. (Dichagyris) terminicincta Corti, 1933

D. (Dichagyris) taftana taftana Brandt, 1941

D. (Dichagyris) taftana elborsasta Varga, Ronkay et Ronkay ssp. $\mathbf{n}$.

D. (Dichagyris) taftana safavida Varga, Ronkay et Ronkay ssp. n.

D. (Dichagyris) guentereberti Varga, Ronkay et Ronkay sp. $\mathbf{n}$.

D. (Dichagyris) celebrata (Alphéraky, 1897)

D. (Dichagyris) humilis (Boursin, 1940)

D. (Dichagyris) hypotacta Varga, Ronkay et Ronkay sp. n.

D. (Dichagyris) ignara (Staudinger, 1896)

D. (Dichagyris) verecunda (Püngeler, 1898)

D. (Dichagyris) karakorealis Varga, Ronkay et Ronkay, 2020

D. (Dichagyris) singularis (Staudinger, 1877)

D. (Dichagyris) melanofusca Varga, Ronkay et Ronkay, 2020

D. (Dichagyris) candelisequa (Denis et Schiffermüller, 1775)

D. (Dichagyris) forficula forficula (Eversmann, 1851)

D. (Dichagyris) forficula hadjina (Staudinger, 1892)

D. (Dichagyris) devota (Christoph, 1884) 
D. (Dichagyris) turana turana (Staudinger, 1892)

D. (Dichagyris) turana furiosa (Bang-Haas, 1912)

D. (Dichagyris) erubescens (Staudinger, 1892)

D. (Dichagyris) contermina (Corti, 1930)

D. (Yigoga) flavina (Herrich-Schäffer, [1852])

D. (Yigoga) truculenta (Lederer, 1853)

D. (Albocosta) musiva (Hübner, [1803])

D. (Albocosta) juldussi (Alphéraky, 1882)

D. (Albocosta) ulrici (Corti et Draudt, 1933) 